\title{
高速伝送対応基板の最新動向
}

\author{
田中 顕裕 *, 野㟝 孝英 *, 本木 浩之*, 池田 聡*, 中西 秀行 *
}

\section{Latest Trend of PCB for High-Speed Signal Transmission}

Akihiro TANAKA*, Takahide NOZAKI*, Hiroyuki MOTOKI*, Satoshi IKEDA*, and Hideyuki NAKANISHI*

*RITA エレクトロニクス株式会社（† 461-0004 愛知県名古屋市東区葵 3-15-31 千種ニュータワービル 14 階）

* RITA Electronics, Ltd. (Chikusa New Tower Building 14F, Aoi 3-15-31, Higashi-ku, Nagoya, Aichi 461-0004)

\section{1. はじめに}

半導体デバイス間の信号の入出力は高速化しており, 速 度や伝送距離によっては光配線が必要といわれている ${ }^{1)}$ 一方で従来の銅配線による高速伝送対応が進んでおり, 年々進化している状況にある。図 1 はプリント配線板にお ける高速シリアル伝送の部位と高速化のトレンドを表した
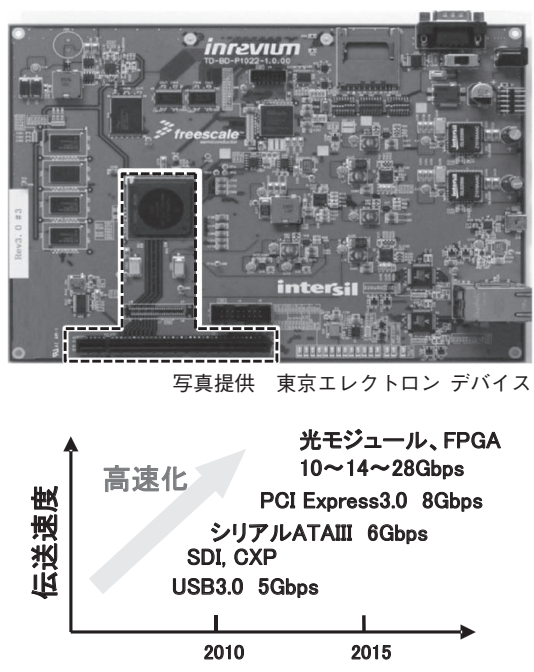

図 1. 高速シリアル伝送の部位とトレンド
ものである。差動伝送では $28 \mathrm{Gbps}$, シングルエンド伝送 では 12 Gbps が実用化されはじめている。このような高速 な信号入出力のある半導体デバイスを適切に機能させ, 困 2 に示すような伝送波形やリターンロスの仕様に合致させ るためには，信号の送り側 $(\mathrm{Tx})$ と受け側 $(\mathrm{Rx})$ との間の基 板配線, コネク夕, ケーブル等で構成される伝送線路のイ ンピーダンス制御が必要である。基板配線が長く，伝送損 失が大きくなる場合には，プリント配線板の材質として通 常よりも低損失なものを選択することもある。基板配線だ けでなく，これに関連する平行平板共振に起因する透過特 性の劣化が生じることがあるため，伝送モードができるだ け変化しないような伝送線路設計を行うと共に, 平行平板 共振が起こらないようなプレーンの設計を行う。特にリ ターンロスの仕様合致に関しては, 特性インピーダンスに 関する TDR（Time Domain Refrectmetry；時間領域反射）プ ロファイルを指標としたパターン設計が重要となる。本稿 では以上の最新動向を解説する。

\section{2. プリント配線板の材質}

高速な電気信号が導体を伝搬する際，導体損と誘電損か

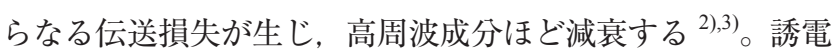
損はガラスエポキシの比誘電率 $\left(\varepsilon_{r}\right.$ 。本稿では $\mathrm{Dk}$ と記す $)$

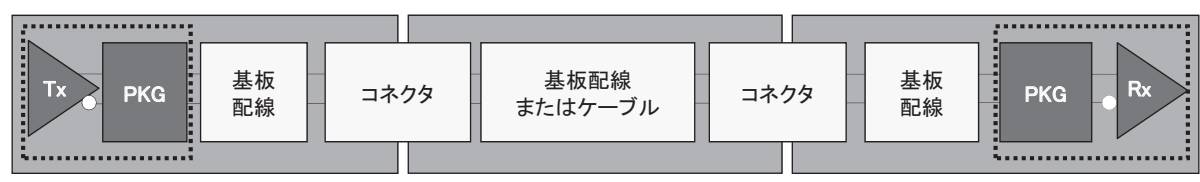

(1)伝送波形

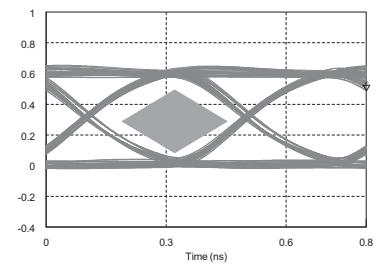

(2)リターンロス

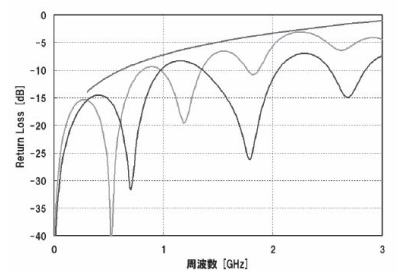

図 2. 高速シリアル伝送の基本構成と規格 
や誘電正接（ $\tan \delta$ 。本稿では Df と記す）の関数であり, こ れらが小さいほど伝送損失は小さくなる。図 3 は差動イン ピーダンス $100 \Omega$ 系で測定したオッドモードの透過特性 Sdd 21 である。 $0 \mathrm{~dB}$ は 100\% 伝搬することを示す。テスト 基板の配線長は $180 \mathrm{~mm}$ で, このうち $30 \mathrm{~mm}$ は外層配線と して, 残り $150 \mathrm{~mm}$ を結合線路として外層または内層に配 置した。この図に表記した Dk P Df は材料メーカによる 1 $\mathrm{GHz}$ における公称值であり，これらが小さいほど損失が小 さいことが分かる。

伝送波形のシミュレーションを行うには, プリント配線 板については信号配線の断面寸法と長さ, および Dk p Df をシミュレーションソフトに入力して周波数特性を求める ことになる。図 4 は絶縁層の材質が一般 FR-4 で, 長さ 100 $\mathrm{mm}$ の外層配線について, 実測とシミュレーションで求め たSdd21 を比較したものである。シミュレーションの方が 損失が小さいことが分かる。これを補正するために例えば

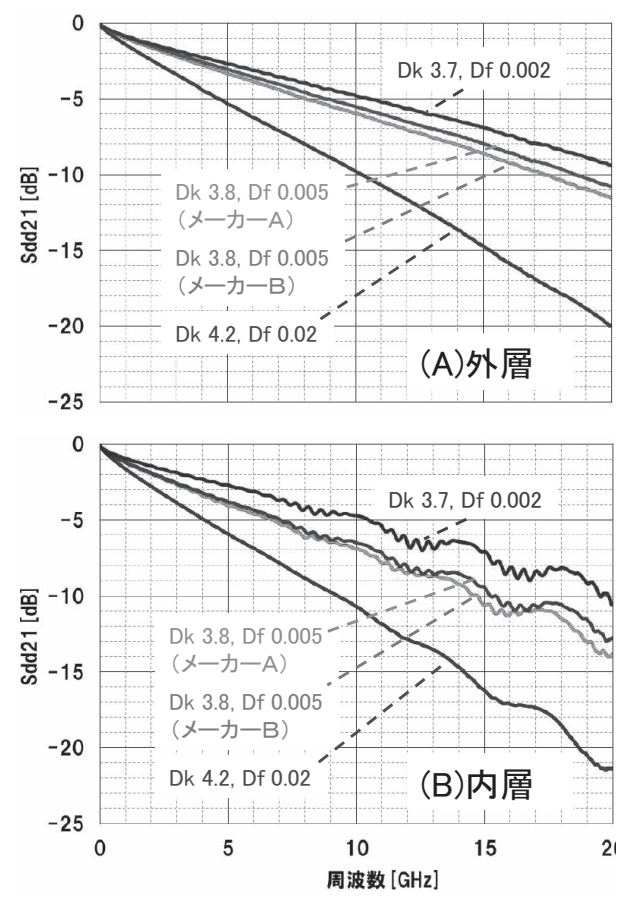

図 3. オッドモード伝送の透過特性 (Sdd21) の実測例

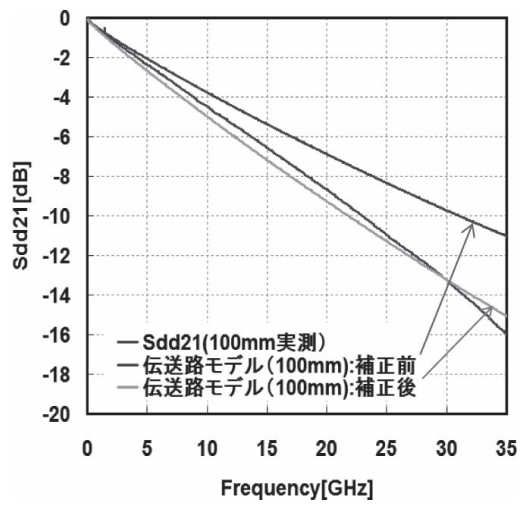

図 4. Sdd21 の実測とシミュレーションの比較
Df について材料メーカ公称値よりも大きい值を用いること で損失量がほぼ実際と合うようにした結果を併記した。伝 送損失のシミュレーションの高精度化は波形シミュレー ションの精度向上のため必須であり, プリント配線板メー カの方で材質毎にシミュレーションソフトに応じた補正值 を見出す必要がある。

\section{3. 伝送線路全体の特性インピーダンス制御とリファ レンスプレーン設計}

プリント配線板の材質について, 絶縁層として低損失・ 低誘電率な材料を用いたり，導体として表面粗さの小さい 銅はくを用いることによって伝送損失の低減を図っても， 基板配線に含まれるビアやパッドなど局所的な部位でイン ピーダンスの不連続点があると信号の高周波成分が反射す るため，高速な信号伝送を実現するには伝送経路全体の特 性インピーダンス制御が必要となる。

ビアのうち，スルーホールについては，信号用の近傍に グラウンド用を設け，これらの位置や穴径，内層のリファ レンスプレーンに扔ける信号スルーホールに対するクリア ランスホールの径を調整することによって TDR 観測上の特 性インピーダンスを配線と同じにすることができる ${ }^{4) 。 こ ~}$ の方法は, $10 \mathrm{Gbps}$ 程度の信号伝送の品質確保には有効で あるが，スタブとよばれる信号経路ではない余分な導体が ある構造では，スタブ長により 4 分の 1 波長共振が生じる 周波数を極大とする伝送損失の劣化が生じる（図 5)。さら なる高速伝送ではスルーホールのスタブ構造に注意が必要 である。図 6 は見かけ上の特性インピーダンスを差動 $100 \Omega$ にコントロールしたスルーホールを含む $100 \mathrm{~mm}$ 長の差動 配線について, $14 \mathrm{Gbps}$ または $28 \mathrm{Gbps}$ の信号を伝搬させ た場合のシミュレーション結果である。スタブがない構造 に対する波形を基準にして，14 Gbps 伝送ではスタブあり の構造でも波形劣化は少ない。しかし $28 \mathrm{Gbps}$ になると波 形が歪むため対策が必要となる。スタブが問題であるとし た場合，これを機械的に除去する加工を施す方法がある。 この加工はバックドリルやカウンターボーリングとよばれ る。この加工を施した差動インピーダンスが $100 \Omega$ のビア

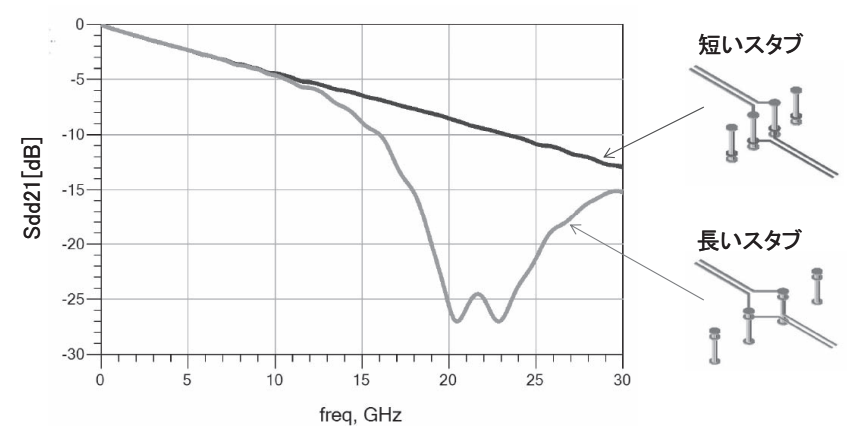

図 5. 特性インピーダンス制御スルーホールを含む差動配 線の Sdd21 


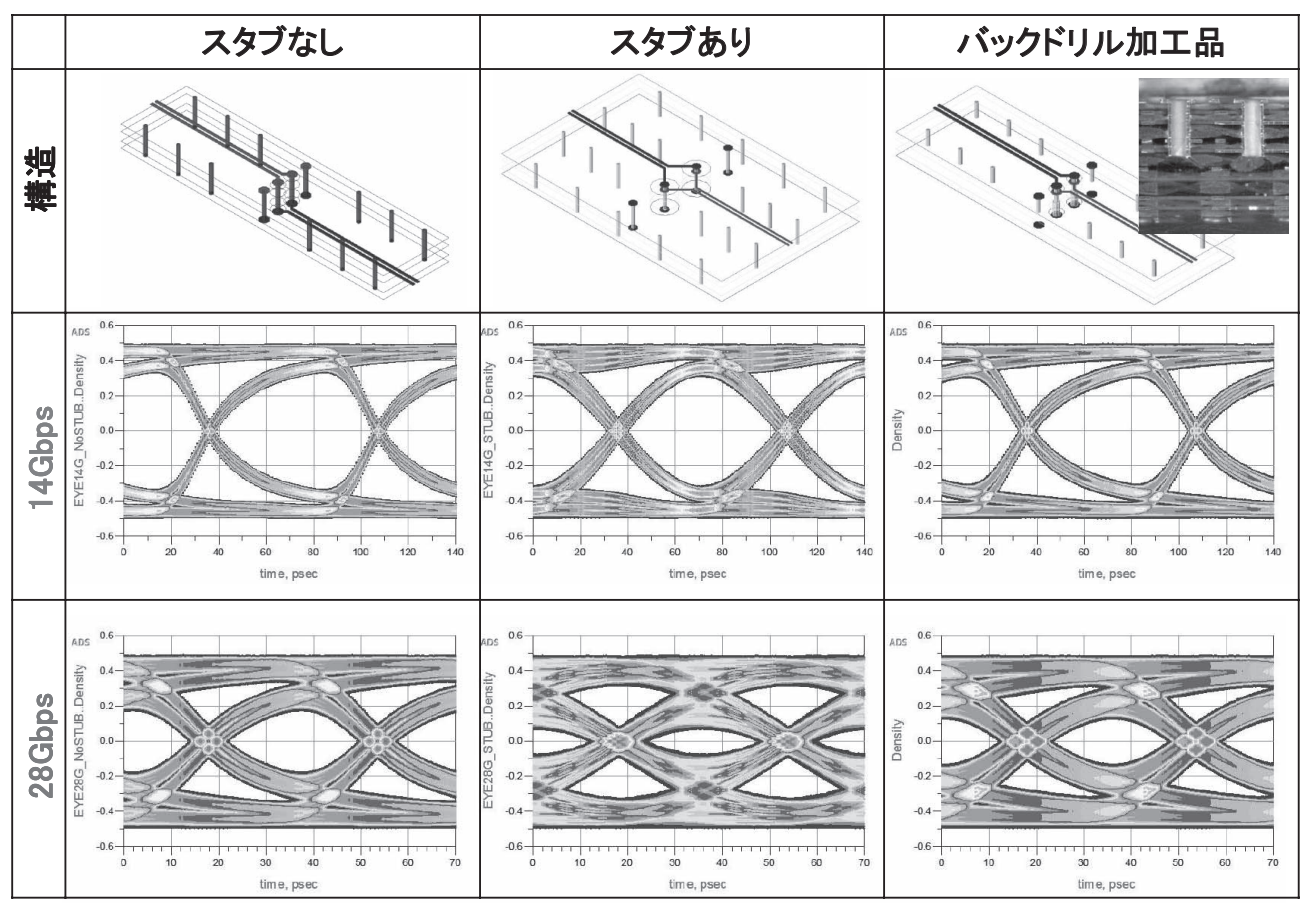

図 6. 特性インピーダンス制御スルーホールの構造と長さ $100 \mathrm{~mm}$ の配線経由後の波形

を含む場合，スタブがあるものと比較して波形が改善され ていることが分かる。高速伝送を実現するうえでの選択肢 となる。

パッドは一般に信号配線よりも太く容量性となるため, インピーダンス不連続点となり，信号の高周波成分が反射 する。これを抑制する手段として，図７に示すようにパッ ド部の内層のベたプレーンに部分的に抜きを設けることに よって寄生容量を少なくして TDR 観測上の特性インピーダ ンスを配線と同じにして伝送特性を改善する方法がある。

なお，ビアとパッドの設計を最適化して，伝送経路全体 の特性インピーダンスを制御しても, 図 8 に示すような伝 送損失の劣化が生じる場合がある。これは，プリント配線 板の外層から内層への信号伝搬にともない伝送モードが変 化し，プレーン同士の短絡点を節とする共振が生じる周波 数ではノイズとなり，その周波数の信号が伝搬し難くなっ た結果と考えられる。したがって, プリント配線板で高速 な信号伝送を実現するためには, 伝送経路全体の特性イン ピーダンスを制御するだけでなく，プレーン共振の抑制も 重要である。この手法としては, プレーン同士の短絡点間 の距離を短くするビアを設ける方法や，プレーン間の絶縁 層厚みを薄くする方法などがある。

以上のビアとパッドに対する特性インピーダンス制御の 実例として, FPGA ${ }^{\dagger}-\mathrm{SFP}+$ 光トランシーバ ${ }^{\dagger}$ 間の $14 \mathrm{Gbps}$ 伝送について適用した例を図 9 に示す。最適化前の状態で は, BGA 実装部におけるスルーホールのスタブと, 光トラ ンシーバ実装部位でのパッドの寄生容量によって，これら 箇所で特性インピーダンスの低下がみられる。Sdd21の ディップはスタブ長に対応したものである。これに対し
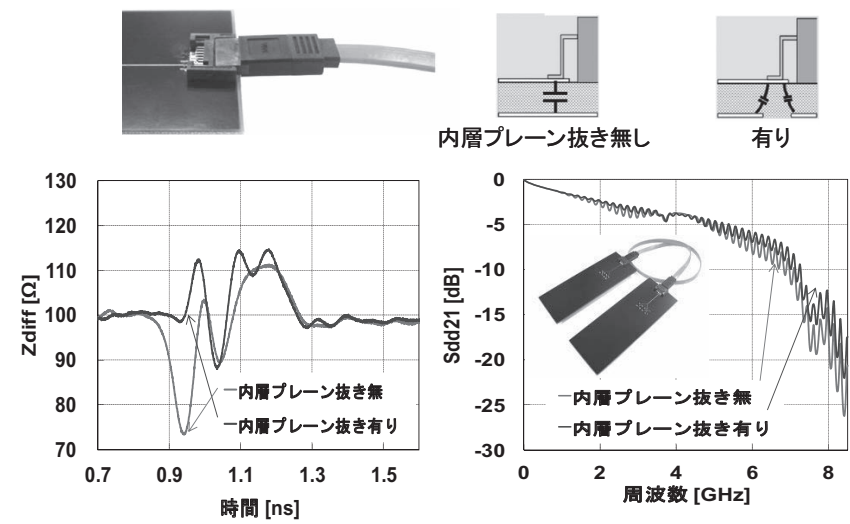

図 7. 部品実装用パッドの特性インピーダンス制御と Sdd 21

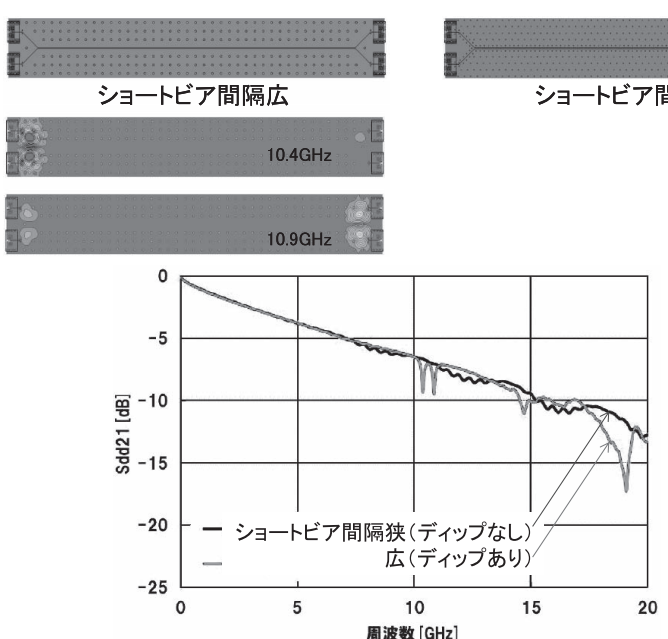

図 8. ストリップライン上下のグラウンドプレーン設計と Sdd 21 
て，BGA 実装部のスルーホールからの配線引き出しについ てスタブが短くなるような配線層を選択し, 光トランシー バ実装用パッドの内層のリファレンスプレーンに抜きを設 けることによって, これら箇所の特性インピーダンスをほ ぼ配線と同じにでき，Sdd21 は改善され，アイパターンも 良好になる。

パターン設計段階においてビアやパッドの特性を求める には, 高精度な電磁界シミュレーションソフトウェアの適 用が必要である。この運用の前に, 実測とシミュレーショ ンの差異を実験的に確認して，適用可能な範囲を明確にし
ておく。

$10 \mathrm{Gbps}$ クラスの高速シリアル伝送では, 半導体デバイ ス間の伝送線路による損失を補正する手段として，送信側 出力部でのプリエンファシスや, 受信側入力部でのリニア イコライザや判定帰還型イコライザ (DFE) などがある ${ }^{5)} 。$ これら機能を活用することで，プリント配線板の材質とし て特殊なものを用いる必要がなくなり，もって低コスト化 が可能になる。この半導体デバイスの補正機能に関しても シミュレーションで試すことができる ${ }^{4)}$ 。図 10 は半導体が 出力する $14 \mathrm{Gbps}$ 信号を基板配線とコネクタ, 同軸ケーブ

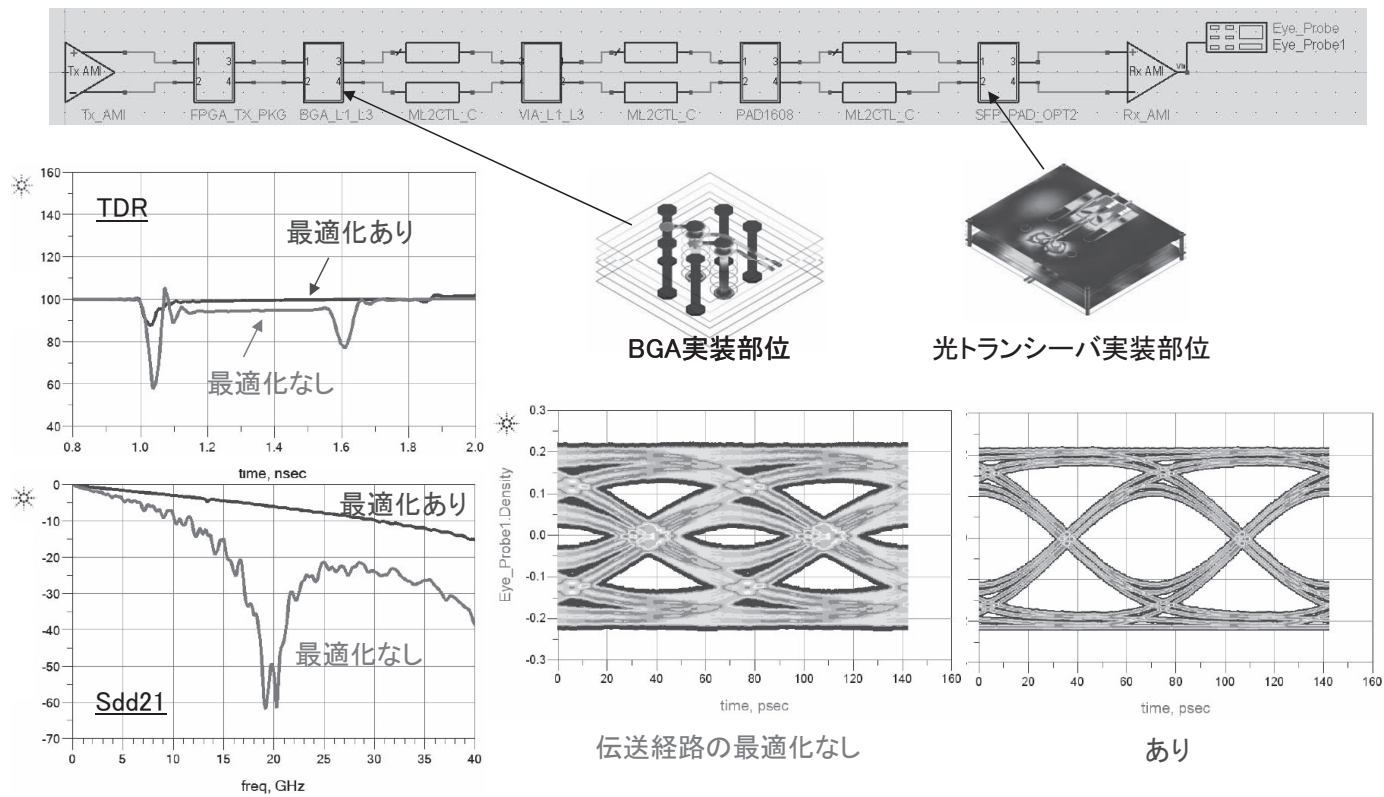

図 9. 伝送経路の最適化による 14 Gbps 信号波形の改善例
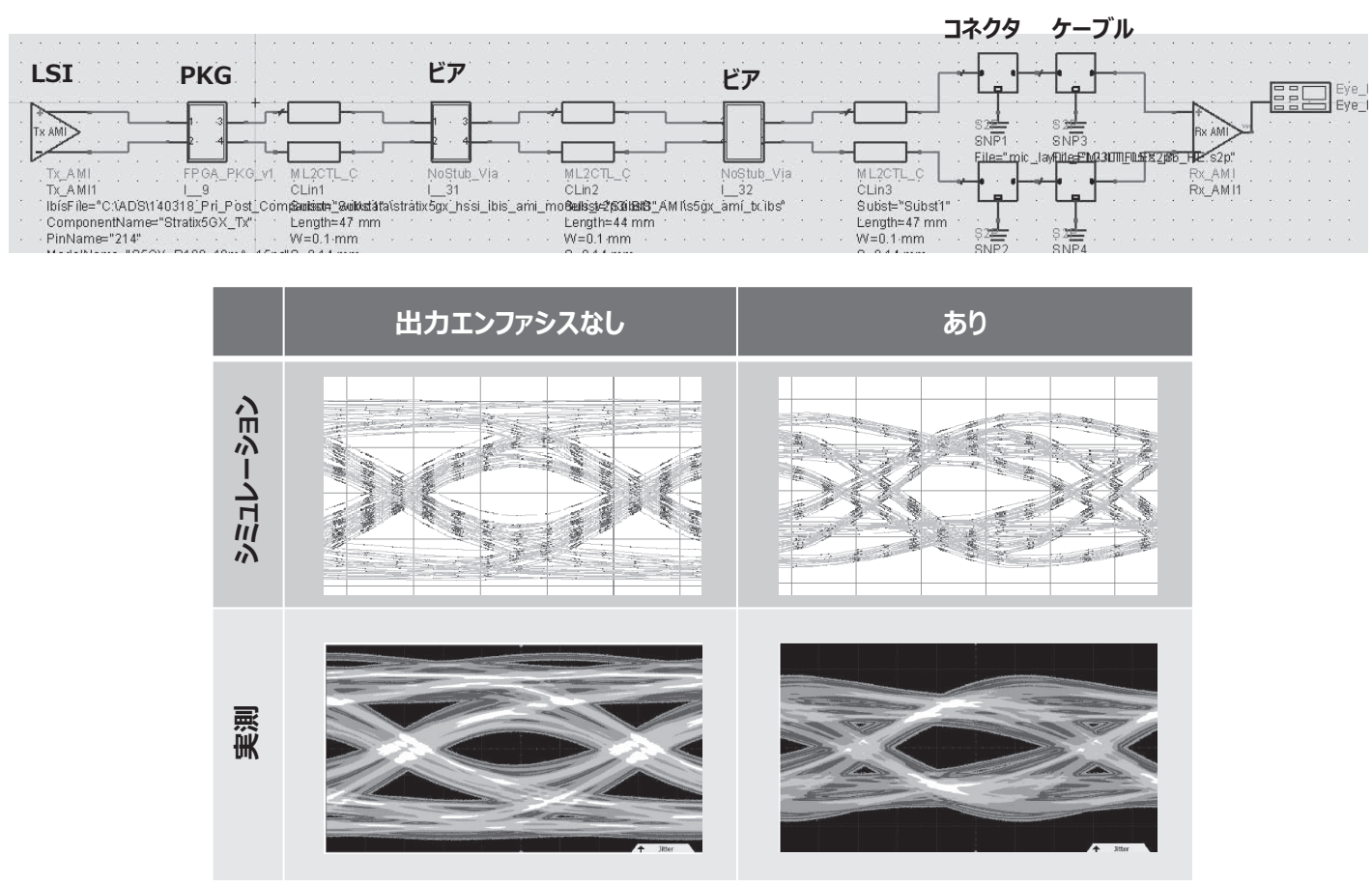

図 10. $14 \mathrm{Gbps}$ 信号波形の実測とシミュレーションの比較 

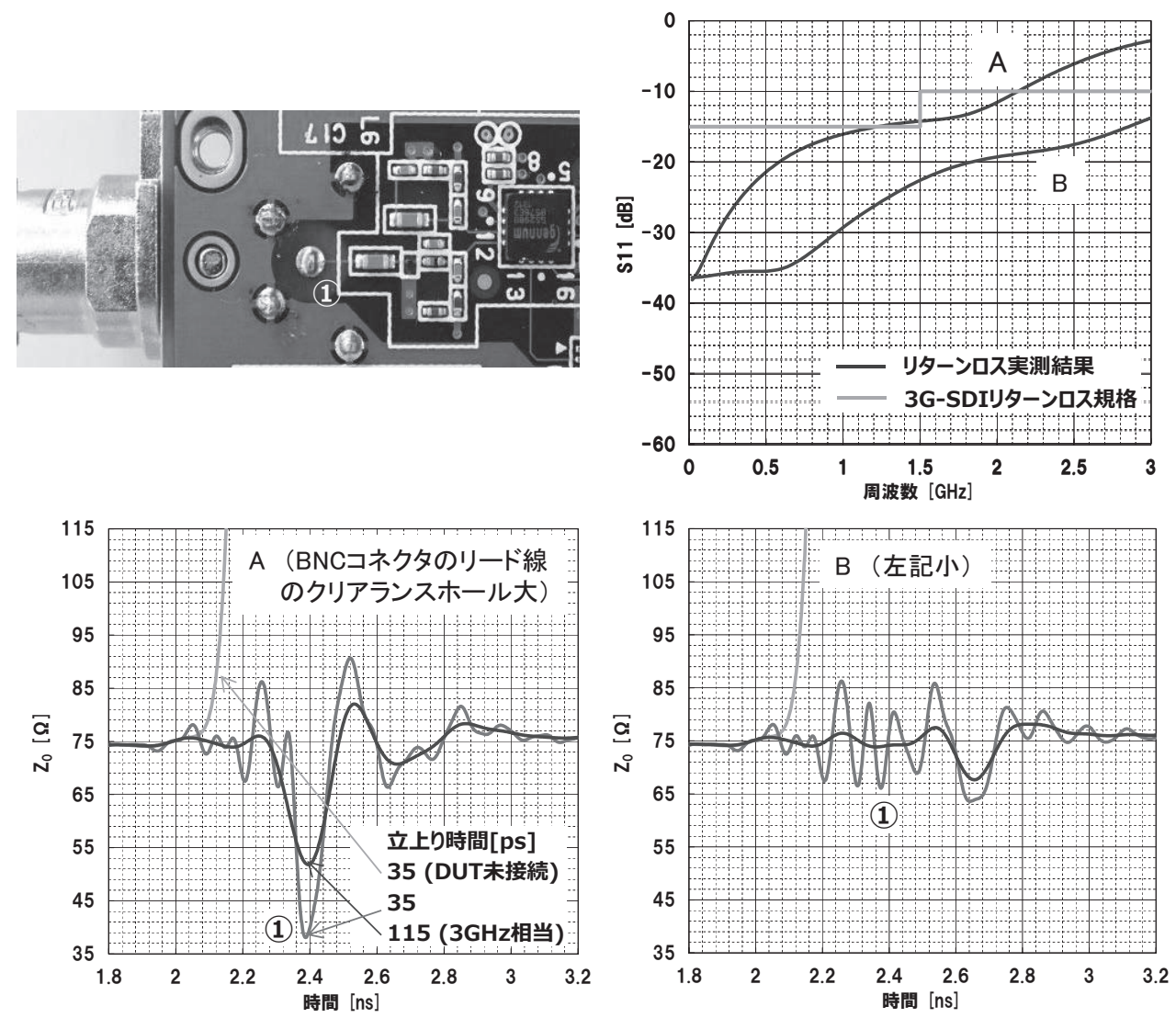

図 11. リターンロスと TDR プロファイルとの関係（3G SDI の場合）

ルを経由して $50 \Omega$ 系のサンプリングオシロで受けた場合 のシミュレーションと実測の比較である。出力におけるプ リエンファシスの有無を反映したアイパターンとなってお り，これは実測とも良く対応していることがわかる。

\section{4. リターンロス仕様対応}

高速シリアル伝送では, 伝送波形の時間や電圧の仕様 (アイマスク) だけでなく、リターンロスの上限が定められ ている規格がある。シリアル・デジタル・インタフェース (SDI) が代表例である。

このリターンロス仕様合致の手法は，規格毎に定められ たインピーダンスを基準に, 伝送経路の TDR プロファイル において特性インピーダンスが高くなる（誘導性）部位が ある場合は，それに続く簓所には低くなる（容量性）部位 を設け，これらが繰り返すような設計を行うことである。 この TDR プロファイルは, リターンロスの仕様で定められ た上限の周波数に対応した立ち上がり時間を採用すること によって, 基準となるインピーダンスからの誘導性, 容量 性のバランスが啇切であるかを判断しやすくなる。

図 11 は $3 \mathrm{G} \mathrm{SDI}$ の例であり, シングルエンド $75 \Omega$ 系で ある。SDI インタフェースで一般的な BNC コネクタについ ては，あらかじめネットワークアナライザーで反射特性を 実測し，これから TDR プロファイルを求めておく。パター ン設計においては, BNC コネクタ内における誘導性の部位
を補償するよう、コネクタの信号リード線のプリント配線 板への実装部に扔いて，内層のリファレンスプレーンのク リアランスホールの径を調整することで容量性になるよう にする。クリアランスホール径が比較的小さい A の場合 は, TDR プロファイルより容量性が過多であり, 結果とし てリターンロスは3G SDI の仕様をオーバーしている。最 適にした場合の B では TDR プロファイルは概ね $75 \Omega$ と なっており，この結果としてリターンロスは仕様に合致す るようになることがわかる。

プリント配線板の設計段階でこの TDR プロファイルを指 標としたリターンロス仕様への合致を目指す場合，コネク 夕については現品を入手してネットワークアナライザーを 用いて特性を実測し，プリント配線板に関してはコネクタ から半導体デバイス間のパターン設計データを作成して高 精度な電磁界ソフトウェアで解き，これらを回路シミュ レーターで結合して TDR プロファイルを求めるといった手 法が必要である。

\section{5. まとめ}

高速伝送対応基板の最新動向として, 高速シリアル伝送 をとりあげ，その伝送波形やリターンロスの仕様合致のた めの手法を解説した。この設計の流れを示したのが図 12 で ある。信号の送信側出力部から受信側入力部までの伝送線 路全体を対象として, パターン設計データをもとにした部 


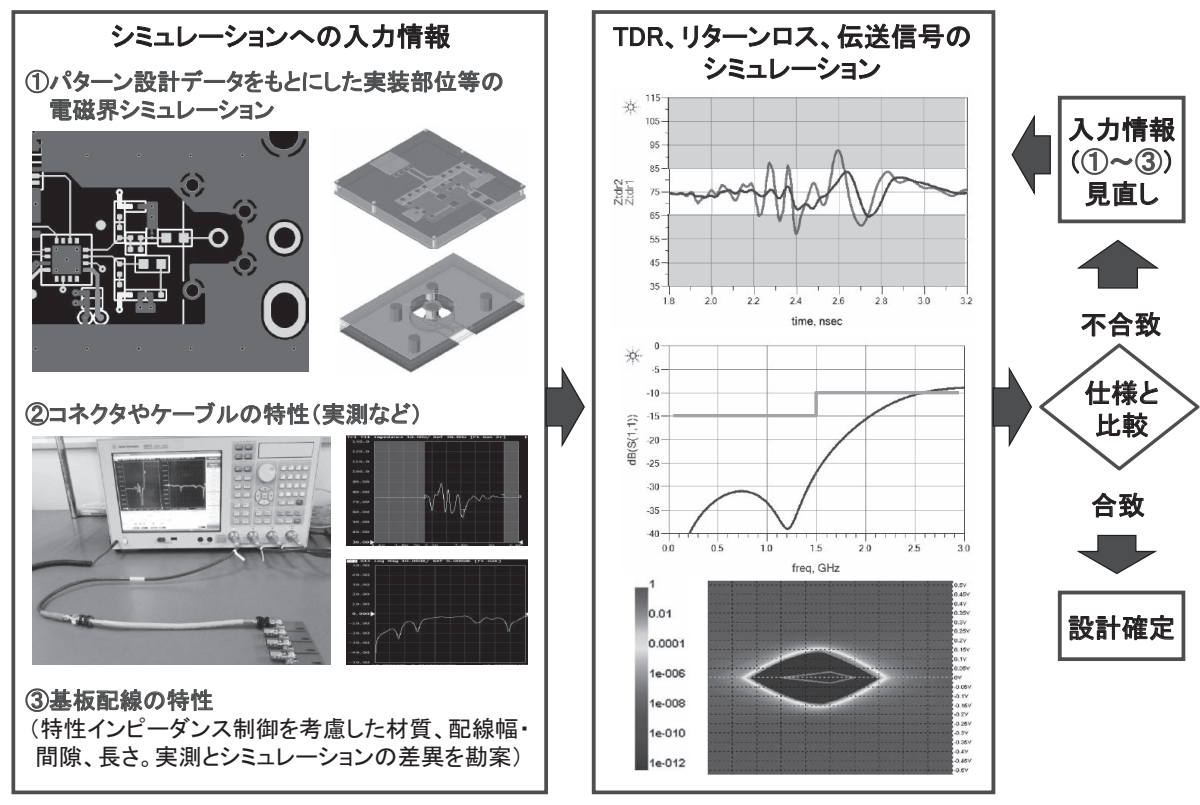

図 12. 高速シリアル伝送対応パターン設計の流れ

分的な電磁界シミュレーションや，部品に対する実測に よって特性を求める。基板配線についてはシミュレーショ ンソフトのモデルを用い, あらかじめ実測との差異を把握 しておき入力パラメータで補正する。このようにして求め た特性を回路シミュレーションで結合して, TDR プロファ イル,リターンロス, 伝送信号のシミュレーションを行 い，仕様に合致しているかを確認する。伝送信号について は半導体の補正機能を活用したシミュレーションを行う。 仕様に対して不合致の場合は，まずパターン設計を見直 し, 次いでプリント配線板の材質の変更を検討する。場合 によっては部品の再選定が必要となる。このような手法に よって，高速シリアル伝送に対応したプリント配線板を効 率よく開発できるようになる。

(2015.6.25- 受理)

\section{文献}

1) 三上 修: “光電気実装技術の変遷と将来展望, ”信学論 (C), Vol. J92-C, No. 8, pp. 404-411, 2009

2) 豊田英弘，西村信二，金井久亮，工藤 整，田中治光：“10 Gbit/s 高周波信号伝送に適したプリント配線板構造と特性 評価,”信学論 (C), Vol. J87-C, No. 11, pp. 847-856, 2004

3) 田中顕裕：“高速差動伝送に対応したプリント配線板パター ン設計の実際,”エレクトロニクス実装学会誌, Vol. 8, No. 4, pp. 271-276, 2005

4) 中西秀行 : “差動伝送路の設計と信号品質, ” エレクトロニ クス実装学会誌, Vol. 16, No. 3, pp. 181-186, 2013

5) 山口晃一：“10 Gbit/s クラスの高速信号伝送を実現する波形 成形回路の動作原理と最新動向,”信学論 (C), Vol. J95-C, No. 5, pp. $93-100,2012$

\section{$\dagger$ 用語解説}

FPGA : Field Programmable Gate Array の略。プログラミ ングすることができる LSI のこと。幅広い用途での使 用が想定されており，特にハイエンド品では高速メモ リDDR4-SDRAM や高速シリアル $28 \mathrm{Gbps}$ など，最新 の高速インタフェースに対応する機能を有しているこ とが多い。

SFP+ 光トランシーバ : MSA (Multi Source Agreements) に よって規定された SFP+ (Small Form-factor Pluggable +) という形状の，電気信号と光信号を相互変換し送受信 するための光トランシーバ。プリント配線板上のコネ ク夕を介し，高速差動信号の入出力機能を有する LSI と電気的に接続される。この伝送速度として $14 \mathrm{Gbps}$ のものがある。

田中顕裕（たなか あきひろ）

著者紹介

RITA エレクトロニクス（株）（2014 年 4 月アイイ力業（株）のプリ ント配線板事業一式を継承して発足したプリント配線板メーカー）執行 役員。プリント配線板の高速信号伝送・ノイズ対策を中心とした新商品 開発とマーケティングに従事。

野㟝孝英（のざき たかひで）

RITA エレクトロニクス（株）にてプリント配線板の高速信号伝送・ ノイズ対策を中心とした新商品開発とコンサルティングに従事。

本木浩之（もとき ひろゆき）

RITA エレクトロニクス（株）にてプリント配線板の高速信号伝送・ ノイズ対策を中心とした新商品開発とコンサルティングに従事。iNARTE 認定 EMC エンジニア。

池田 聡（いけださとし）

RITA エレクトロニクス（株）にてプリント配線板の高速信号伝送 · ノイズ対策を中心とした新商品のマーケティングに従事。iNARTE 認定 EMC エンジニア。

中西秀行（なかにし ひでゆき）

RITA エレクトロニクス（株）にてプリント配線板の高速信号伝送・ ノイズ対策を中心とした新商品開発とコンサルティングに従事。 